COSTING: Journal of Economic, Business and Accounting

Volume 2 Nomor 2, Juni 2019

e-ISSN : 2597-5234

https://doi.org/10.31539/costing.v2i2.547

\title{
ANALISIS KOMPETENSI TERHADAP KINERJA PEGAWAI
}

\section{ANALYSIS OF COMPETENCY ON EMPLOYEE PERFORMANCE}

\author{
Hafidzah Nurjannah \\ Fakultas Ekonomi, Universitas Islam Riau \\ hafidzahnurjannah@eco.uir.ac.id \\ Submit, 06-02-2019 Accepted, 03-04-2019 Publish,03-04-2019
}

\begin{abstract}
Performance in carrying out its functions does not stand alone, but is related to work ability and motivation. This study aims to determine how the influence of competencies (knowledge, skills, self-concept and value, and personal characteristics) on the performance of employees of the Islamic University of Riau. The population used in this study were all employees of the Islamic University of Riau, amounting to 130 people, while the sample method used in this study was the census method. After distributing questionnaires to 130 respondents but the questionnaire returned only 60 copies so that the sample in this study were 60 respondents. The results of this study indicate that the $t$ test, namely knowledge, skills, self-concept and value, and personal characteristics have a positive and significant effect partially on the performance of UIR employees. The results of the analysis through the F test show that Knowledge, Skills, Self-concept and value, and Personal Characteristics have a positive and significant effect on the performance of UIR employees.
\end{abstract}

Keywords: Knowledge, Skills, Self-concept and Value, Personal Characteristics, Employee Performance

\begin{abstract}
ABSTRAK
Kinerja dalam menjalankan fungsinya tidak berdiri sendiri, tetapi berhubungan dengan kemampuan dan motivasi kerja. Penelitian ini bertujuan untuk mengetahui bagaimana pengaruh kompetensi (pengetahuan, keterampilan, konsep diri dan nilai, serta karakteristik pribadi) terhadap kinerja pegawai Universitas Islam Riau. Populasi yang digunakan dalam penelitian ini adalah seluruh pegawai Universitas Islam Riau yang berjumlah 130 orang, sedangkan metode sample yang digunakan dalam penelitian ini adalah metode sensus. Setelah penyebaran kuesioner kepada 130 responden tetapi kuesioner yang kembali hanya 60 eksemplar sehingga sampel dalam penelitian ini sebanyak 60 responden. Hasil penelitian ini menunjukkan bahwa uji $t$ yaitu pengetahuan, keterampilan, konsep diri dan nilai, serta karakteristik pribadi berpengaruh positif dan signifikan secara parsial terhadap kinerja pegawai UIR. Hasil analisis melalui uji F menunjukkan bahwa Pengetahuan, Keterampilan, Konsep diri dan nilai, serta Karakteristik Pribadi berpengaruh positif dan signifikan terhadap kinerja pegawai UIR.
\end{abstract}

Kata Kunci : Pengetahuan, Keterampilan, Konsep Diri dan Nilai, Karakteristik Pribadi, Kinerja Pegawai 


\section{PENDAHULUAN}

Kinerja dalam menjalankan fungsinya tidak berdiri sendiri, tetapi berhubungan dengan kemampuan dan motivasi kerja. Oleh karena itu menurut Keith Davis (dalam Mangkunegara, 2005), ada dua faktor utama yang mempengaruhi kinerja individu yakni kemampuan (ability), dan motivasi kerja (motivation) individu tersebut. Kemampuan individual tergantung dari tingkat pengetahuan (knowledge) yang dimiliki, latarbelakang pendidikan, dan keterampilan (skill) yang dikuasai. Sedangkan motivasi kerja individual tergantung sikap (attitude) sebagai motivasi dasar dan lingkungan yang mempengaruhi motivasi tersebut.

Pembinaan dan peningkatan kinerja individu dapat dilakukan dengan pembinaan dan peningkatan kemampuan dan motivasi kerja yang dimiliki. Peningkatan kemampuan kerja dilakukan dengan upaya peningkatan aspek-aspek yang mendasari unsur tersebut yakni pengetahuan dan keterampilan kerja individu serta peningkatan motivasi kerja dilakukan dengan cara membina sikap mental individu serta situasi/lingkungan yang mendorong timbulnya kepuasan dan kemauan kerja individu (Bacal, 2005).

Menuju Perguruan tinggi yang ber-Badan Hukum Perguruan Tinggi, maka Universitas Islam Riau terus berupaya meningkatkan kualitas proses belajar mengajar dimana sasaran akhir adalah terjadinya peningkatan kualitas lulusan yang unggul dan kompetitif, memberdayakan seluruh pegawai agar dapat bekerja secara optimal, efektif dan efisien.

Langkah antisipasi secara total yang diperlukan untuk menghasilkan lulusan yang mandiri, profesional dan kompetitif tersebut maka perlu meningkatkan kinerja pegawai Universitas Islam Riau (UIR) dengan penguasaan pengetahuan (cognitive), penguasaan keterampilan (psychomotoric), Pengembangan sikap mental (affective), dan

Pengorientasian pada pekerjaan (transferability).

Pengelolaan pendidikan tinggi mutlak harus dilakukan dengan sebaikbaiknya mengingat dewasa ini pendidikan tinggi di Indonesia diperhadapkan pada masa depan yang penuh tantangan, karena laju perubahan bergerak sangat cepat, tuntutan masyarakat semakin tinggi, kehidupan sangat dipengaruhi oleh perkembangan ilmu pengetahuan dan teknologi, dan faktor-faktor lain yang kompleks dalam era globalisasi ini.

Kompetensi adalah suatu kemampuan untuk melaksanakan atau melakukan suatu pekerjaan atau tugas yang dilandasi atas keterampilan dan pengetahuan serta didukung oleh sikap kerja yang dituntut oleh pekerjaan tersebut. Kompetensi sebagai kemampuan seseorang untuk menghasilkan pada tingkat yang memuaskan di tempat kerja, juga menunjukkan karakteristik pengetahuan dan keterampilan yang dimiliki atau dibutuhkan oleh setiap individu yang memampukan mereka untuk melakukan tugas dan tanggung jawab mereka secara efektif dan meningkatkan standar kualitas professional dalam pekerjaan (Murgiyono 2002).

Pengetahuan pegawai turut menentukan berhasil tidaknya pelaksanaan tugas yang dibebankan kepadanya, pegawai yang mempunyai pengetahuan yang cukup akan meningkatkan efisiensi perusahaan.

1. Keterampilan : Pegawai yang mempunyai kemampuan kerja yang baik, maka akan mempercepat pencapaian tujuan organisasi, sebaliknya pegawai yang tidak terampil. akan memperlambat tujuan organisasi. Untuk pegawaipegawai 
baru atau pegawai dengan tugas baru diperlukan tambahan kemampuan guna pelaksanaan tugas-tugas yang dibebankan kepadanya.

2. Konsep diri dan nilai-nilai : Disamping pengetahuan dan ketrampilan pegawai, hal yang perlu diperhatikan adalah sikap atau perilaku kerja pegawai. Apabiia pegawai mempunyai sifat yang mendukung pencapaian tujuan organisasi, maka secara otomatis segala tugas yang dibebankan kepadanya akan dilaksanakan dengan sebaik-baiknya.

3. Karakteristik pribadi : Karakteristik pribadi merupakan cerminan bagaimana seorang pegawai mampu/tidak mampu melakukan suatu aktivitas dan tugas secara mudah/sulit dan sukses/tidak pernah sukses.

4. Motif : Motif adalah kekuatan pendorong yang akan mewujudkan suatu perilaku guna mencapai tujuan kepuasan dirinya.

Performance berasal dari kata to perform yang mempunyai beberapa masukan (entries), yakni (1) melakukan,

(2) memenuhi atau menjalankan suatu,

(3) melaksanakan suatu tanggung jawab, (4) melakukan sesuatu yang diharapkan oleh seseorang (Dharma 2005). Dari masukan tersebut dapat diartikan, kinerja adalah melakukan suatu kegiatan dan menyempurnakan pekerjaan tersebut sesuai dengan tanggung jawabnya sehingga dapat mencapai hasil sesuai dengan yang diharapkan.

\section{METODE PENELITIAN}

Yang menjadi objek dalam penelitian ini adalah pegawai Universitas Islam Riau. Teknik sampel yang digunakan yaitu sampling jenuh (sensus) sebanyak 130 orang.

\section{Jenis dan Sumber Data}

Data yang digunakan dalam penelitian ini adalah data sekunder yang diperoleh dari berbagai informasi antara lain buku, kuesioner, pengamatan (observasi), dan lain sebagainya. Datadata juga dikumpulkan dengan mengakses berbagai situs yang relevan.

Uji validitas digunakan untuk mengukur sah atau valid tidaknya suatu kuesioner. Suatu kuesioner dikatakan vaid jika pertanyaan pada kuesioner mampu untuk mengungkapkan sesuatu yang akan diukur oleh kuesioner tersebut. Pengujian

validitas ini menggunakan Pearson Correlation yaitu dengan cara menghitung korelasi antara skor masing-masing butir pertanyaan dengan total skor masing-masing skor. Jika korelasi antara skor masing-masing butir pertanyaan dengan total skor mempunyai tingkat signifikansi di bawah 0,005 maka butir pertanyaan tersebut dinyatakan valid dan sebaliknya (Ghozali, 2009).

Uji Reliabilitas merupakan alat untuk mengukur suatu kuisioner yang merupakan indikator dari variabel atau konstruk. Suatu kuesioner dikatakan reliabel atau handal jika jawaban seseorang terhadap pertanyaan konsisten atau stabil dari waktu ke waktu. SPPS memberikan fasilitas untuk mengukur reliabilitas dengan uji statistik Cronbach Alpha ( $\alpha$ ). Suatu variabel dikatakan reliabel jika memberikan nilai $\alpha>0,60$ (Ghozali, 2009).

\section{Teknik Analisis Data}

Pengujian hipotesis akan
dianalisis dengan berganda sedangkan untuk melihat tingkat pengaruh Pengetahuan, Keterampilan, Konsep diri dan nilai, Karakteristik Pribadi terhadap kinerja pegawai Universitas Islam Riau secara parsial menggunakan uji t. uji $t$ dilakukan dengan cara membandingkan 
nilai thitung dengan $\mathrm{t}$ tabel atau dengan melihat nilai $P_{\text {value }}$ masing-masing variabel, sehingga dapat ditemukan apakah hipotesis yang telah dibuat signifikan atau tidak signifikan. Uji $\mathrm{F}$ dilakukan untuk menguji apakah Pengetahuan, Keterampilan, Konsep diri dan nilai, Karakteristik Pribadi berpengaruh terhadap kinerja pegawai Universitas Islam Riau secara simultan (Sugiyono 2015).

\section{HASIL DAN PEMBAHASAN}

Instrumen penelitian yang digunakan adalah kuesioner yang merupakan hasil rancangan yang dibangun dari kombinasi informasi hasil observasi awal, wawancara dan teori. Kuesioner ini telah melalui tahap uji validitas dan reliabilitas dalam pilot study, sehingga terbukti secara empirik layak untuk dijadikan instrument penelitiaan.

\section{Pengaruh Pengetahuan Terhadap Kinerja Pegawai Universitas Islam Riau}

Berdasarkan hasil perhitungan diketahui bahwa nilai koefisien korelasinya sebesar 0,392. Koefisien korelasi bernilai positif sehingga mencerminkan bahwa semakin tinggi pengetahuan pegawai Universitas Islam Riau, maka akan semakin tinggi kinerja Pegawai Universitas Islam Riau. Hasil uji $\mathrm{t}$ yang digunakan untuk menguji hipotesis menunjukkan hasil thitung $=$ 3,240 . Adapun nilai tabel menggunakan taraf signifikansi $\alpha=0,05(5 \%)$ dan degree of freedom sebesar 58 yaitu 1,672. Karena nilai thitung $=3,240>$ tabel $=1,672$, maka hipotesis

diterima.Dengan demikian dapat disimpulkan bahwa pengetahuan berpengaruh positif dan signifikan terhadap kinerja pegawai Universitas Islam Riau.

Hal ini menunjukkan bahwa pengetahuan sangat penting dan vital bagi kinerja pegawai Universitas Islam
Riau. Kondisi ini dapat dipahami karena kemampuan berpikir secara analitis terhadap sesuatu yang kompleks, memiliki kemampuan berpikir kreatif, dapat memahami masalah

dan mampu memecahkan masalah, dapat mengembangkan pengetahuan yang dimiliki (Palan 2007).

Pengaruh Keterampilan terhadap Kinerja Pegawai Universitas Islam Riau

Berdasarkan hasil perhitungan dapat diketahui bahwa nilai koefisien korelasinya sebesar 0,349. Koefisien korelasi bernilai positif sehingga mencerminkan bahwa semakin tinggi keterampilan yang dimiliki pegawai Universitas Islam Riau, maka akan semakin tinggi kinerja Pegawai Universitas Islam Riau. Hasil uji t yang digunakan untuk menguji hipotesis menunjukkan hasil thitung $=2,832$. Adapun nilai tabel menggunakan taraf signifikansi $\alpha=0,05(5 \%)$ dan degree of freedom sebesar 58 yaitu 1,672. Karena nilai thitung $=2,832>$ tabel $=1,672$, maka hipotesis diterima. Dengan demikian dapat disimpulkan bahwa keterampilan berpengaruh positif dan signifikan terhadap kinerja pegawai Universitas Islam Riau.

Hal ini menunjukkan bahwa keterampilan sangat penting dan vital bagi kinerja pegawai Universitas Islam Riau. Kondisi ini dapat dipahami karena mengerjakan pekerjaan atas inisiatif sendiri atau tanpa menunggu diperintah, menyusun jadwal sehingga mahasiswa tidak terlalu lama menunggu terkait dengan dokumen yang dieprlukan, kecepatan pegawai dalam menyelesaikan tugasnya, ketelitian dalam menyusun ataupun membuat dokumen mahasiswa.

\section{Pengaruh Konsep Diri dan Nilai terhadap Kinerja Pegawai Universitas Islam Riau}

Berdasarkan hasil perhitungan dapat diketahui bahwa nilai koefisien korelasinya sebesar 0,343. Koefisien 
korelasi bernilai positif sehingga mencerminkan bahwa semakin tinggi konsep diri dan nilai yang dimiliki pegawai Universitas Islam Riau, maka akan semakin tinggi kinerja Pegawai Universitas Islam Riau. Hasil uji t yang digunakan untuk menguji hipotesis menunjukkan hasil thitung $=2,782$. Adapun nilai tabel menggunakan taraf signifikansi $\alpha 0,01(1 \%)$ dan degree of freedom sebesar 58 yaitu 1,672. Karena nilai thitung $=2,782>$ tabel $=1,672$ maka hipotesis diterima. Dengan demikian dapat disimpulkan bahwa konsep diri dan nilai berpengaruh positif dan signifikan terhadap kinerja pegawai Universitas Islam Riau.

Hal ini menunjukkan bahwa konsep diri dan nilai sangat penting dan vital bagi kinerja pegawai Universitas Islam Riau. Kondisi ini dapat dipahami karena kemampuan ingin mengembangkan orang lain, mengikuti kemauan dari pimpinan, mampu bekerja sama dalam tim, memiliki kecerdasan emosional dan loyalitas yang tinggi ketika diperlukan serta memiliki kemampuan untuk memahami sesama pegawai.

\section{Pengaruh Karkteristik Pribadi terhadap Kinerja Pegawai Universitas Islam Riau}

Berdasarkan hasil perhitungan sebagaimana dirangkum dalam tabel diatas dapat diketahui bahwa nilai koefisien korelasinya (r) sebesar 0,289. Koefisien korelasi bernilai positif sehingga mencerminkan bahwa semakin tinggi karakteristik pribadi yang dimiliki pegawai Universitas Islam Riau, maka akan semakin tinggi kinerja Pegawai Universitas Islam Riau. Hasil uji t yang digunakan untuk menguji hipotesis menunjukkan hasil thitung $=2,300$. Adapun nilai tabel menggunakan taraf signifikansi $\alpha=0,01(1 \%)$ dan degree of freedom sebesar 58 yaitu 1,672. Karena nilai thitung $=2,400>t_{\text {tabel }}=1,672$, maka hipotesis diterima. Dengan demikian dapat disimpulkan bahwa karakteristik pribadi berpengaruh positif dan signifikan terhadap kinerja pegawai Universitas Islam Riau.

Hal ini menunjukkan bahwa karakteristik pribadi sangat penting dan vital bagi kinerja pegawai Universitas Islam Riau. Kondisi ini dapat dipahami karena kemampuan untuk mengendalikan emosi diri, memiliki keyakinan terhadap diri sendiri, kemampuan dapat menyesuaikan diri dengan berbagai situasi, serta memiliki komitmen yang tinggi (Rivai 2005).

\section{Uji F (Pengaruh Pengetahuan, Keterampilan, Konsep Diri dan Nilai, dan Karakteristik Pribadi terhadap Kinerja Pegawai Universitas Islam Riau)}

Hasil uji F yang digunakan untuk menguji hipotesis menunjukkan hasil Fhitung

$=4,092$. Adapun nilai $F_{\text {tabel }}$ menggunakan taraf signifikansi $\alpha=0,05$ (1\%) yaitu 2,54.

Karena nilai Fhitung (4,092) > Ftabel $(2,54)$, maka hipotesis diterima. Dengan demikian dapat disimpulkan bahwa pengetahuan, keterampilan, konsep diri dan nilai, serta karakteristik pribadi berpengaruh positif dan signifikan terhadap kinerja pegawai Universitas Islam Riau.

Persamaan regresi pengetahuan, keterampilan, konsep diri dan nilai, serta karakteristik pribadi adalah $\mathrm{Y}=$ $49,205+0,853 X_{1}+0,808 X_{2}+0,442 X_{3}$ $+0,451 \mathrm{X}_{4}$. Nilai konstanta sebesar 49,205 dapat dijelaskan bahwa pada saat variabel pengetahuan, keterampilan, konsep diri dan nilai, serta karakteristik pribadi bernilai 0 , maka Kinerja pegawai memiliki nilai tetap sebesar 49,205. Dari persamaan tersebut, juga diketahui koefisien regresi variabel pengetahuan $=0,853$, keterampilan $=$ 0,808 , konsep diri dan nilai $=0,442$, dan karakteristik pribadi $=0,451$. Hal ini 
menunjukkan bahwa setiap kenaikan satu kesatuan pengetahuan, keterampilan, konsep diri dan nilai, serta karakteristik pribadi akan diikuti kenaikan kinerja pegawai Universitas Islam Riau sebesar 0,853 dari pengetahuan, 0,808 dari keterampilan, 0,442 dari konsep diri dan nilai, serta 0,451 dari karakteristik pribadi.

Hal ini menunjukkan bahwa pengetahuan, keterampilan, konsep diri dan nilai, dan karakteristik pribadi sangat penting dan vital bagi kinerja Universitas Islam Riau. Kondisi ini dapat dipahami karena kemampuan berpikir secara analitis terhadap sesuatu yang kompleks, memiliki kemampuan berpikir kreatif, dapat memahami masalah dan mampu memecahkan masalah, dapat mengembangkan pengetahuan yang dimiliki. Demikian pula pegawai harus mengerjakan pekerjaan atas inisiatif sendiri atau tanpa menunggu diperintah, menyusun jadwal sehingga mahasiswa tidak terlalu lama menunggu terkait dengan dokumen yang dieprlukan, kecepatan pegawai dalam menyelesaikan tugasnya, ketelitian dalam menyusun ataupun membuat dokumen mahasiswa. Begitu pula ketika pegawai harus memiliki kemampuan mengembangkan orang lain, mengikuti kemauan dari pimpinan, mampu bekerja sama dalam tim, memiliki kecerdasan emosional dan loyalitas yang tinggi ketika diperlukan serta memiliki kemampuan untuk memahami sesama pegawai. Oleh itu, pegawai harus memiliki kemampuan untuk mengendalikan emosi diri, memiliki keyakinan terhadap diri sendiri, kemampuan dapat menyesuaikan diri dengan berbagai situasi, serta memiliki komitmen yang tinggi.

\section{PENUTUP}

\section{Kesimpulan}

Dari hasil penelitian dapat disimpulkan beberapa hal sebagai berikut :

1. Pengetahuan berpengaruh positif dan signifikan terhadap kinerja pegawai Universitas Islam Riau.

2. Keterampilan berpengaruh positif dan signifikan terhadap kinerja pegawai Universitas Islam Riau.

3. Konsep diri dan nilai berpengaruh positif dan signifikan terhadap kinerja pegawai Universitas Islam Riau.

4. Karakteristik pribadi berpengaruh positif dan signifikan terhadap kinerja pegawai Universitas Islam Riau.

\section{Saran}

Untuk dapat meningkatkan kinerja karyawan, Universitas Islam Riau hendaknya mendorong karyawannya untuk senantiasa meningkatkan kualitas pribadinya melalui pelatihan atau workshop maupun studi lanjut. Bagi penelitian selanjutnya agar dapat mengembangkan penelitian ini dengan variable lain maupun objek penelitian berbeda.

\section{DAFTAR PUSTAKA}

Bacal, Robert. (2005). Performance Management. PT. Gramedia Pustaka Utama. Jakarta.

Dharma, Surya. (2005). Manajemen Kinerja; Falsafah Teori dan Penerapannya, Pustaka Pelajar. Yogyakarta.

Ghozali, Imam. (2009). Aplikasi Analisis Multivariate Dengan Program SPSS, Edisi Keempat, Penerbit Universitas Diponegoro. 
Mangkunegara, A.A. Anwar Prabu. (2005). Evaluasi Kinerja SDM. Refika Aditama. Bandung.

Murgiyono. (2002). Kompetensi Dasar PNS, Konsep Pemikiran Manajemen SDM PNS Berbasis Kompetensi. Jakarta.

Palan, R. (2007). Competency Management. Teknik Mengimplementasikan Manajemen SDM berbasis Kompetensi untuk Meningkatkan Daya Saing Organisasi. Penerjemah: Octa Melia Jalal. Penerbit PPM. Jakarta.

Rivai, Veithzal dan Basri, Ahmad Fawzi Mohd. (2005). Performance Appraisal. PT. Raja Grafindo Persada. Jakarta.

Sugiyono. (2015). MetodePenelitian Manajemen. Bandung: Alfabeta. 